\title{
PEMULIHAN HAK-HAK KORBAN PENYIKSAAN DI TAHANAN KEPOLISIAN SEKTOR SIJUNJUNG, SUMATERA BARAT*
}

\author{
Syafridatati \& Refki Saputra \\ Fakultas Hukum Universitas Bung Hatta \\ Padang - Sumatera Barat \\ Email: refkysaputra@gmail.com \\ DOI: $10.15408 /$ jch.v4i2.3688
}

\begin{abstract}
Since the reform era, there are certain rules and institutions that affect the regime of protection of victims in Indonesia, but not enough to provide protection for victims of torture. In addition to the lack of legal instruments that specifically regulates matters of acts of torture, the perception of inequality among law enforcers is also a major obstacle to the healing process rights of victims of torture. Absence of regulations explicitly declare torture as a crime and violation of human rights can not be postponed again. Because the torture emerged from an authority given country, but lack of control. The workers are in a very vulnerable side for dealing with the state as an actor and also law enforcement. Agency as an independent state institution has a great opportunity to overcome the imbalances which in essence provide more real justice for victims.
\end{abstract}

Keywords: recovery of victims, torture, dressing-loss, restitution

\begin{abstract}
Abstrak: Semenjak era reformasi, muncul beberapa peraturan dan juga institusi yang berpengaruh terhadap rezim perlindungan korban di Indonesia, namun belum cukup mampu memberikan perlindungan yang layak bagi korban penyiksaan. Selain karena ketiadaan instrumen hukum yang mengatur secara khusus ikhwal tindakan penyiksaan tersebut, ketidaksamaan persepsi diantara penegak hukum juga menjadi kendala yang besar bagi proses pemulihan hak korban penyiksaan. Adanya peraturan yang secara eksplisit menyatakan penyiksaan sebagai tindak pidana dan juga pelanggaran HAM tidak bisa ditunda lagi. Pasalnya, penyiksaan muncul dari sebuah kewenangan yang diberikan negara, namun minim kontrol. Selain itu korban berada pada sisi yang sangat rentan karena berhadapan dengan negara sebagai pelaku dan juga penegak hukumnya. LPSK sebagai lembaga negara independen berpeluang besar mengatasi ketimpangan tersebut yang pada intinya memberikan keadilan yang lebih nyata bagi korban.
\end{abstract}

Kata Kunci : pemulihan korban, penyiksaan, ganti-kerugian, restitusi

\footnotetext{
${ }^{*}$ Naskah diterima: 25 Mei 2016, direvisi: 27 Juli 2016, disetujui untuk terbit: 30 September
} 2016. 


\section{Syafridatati \& Refki Saputra}

\section{Pendahuluan}

Dipenghujung tahun 2011, dua orang kakak-beradik, Faisal (14) dan Budri (17) ditemukan tewas dalam ruang tahanan Kepolisian Sektor (Polsek) Muaro Sijunjung, Provinsi Sumatera Barat. Mereka meregang nyawa dalam posisi tergantung dengan potongan kain yang melilit dileher masing-masing. Kematian Faisal dan Budri yang menggemparkan masyarakat di Sumatera Barat tersebut, diduga oleh adanya sebab-sebab kekerasan. Faisal sebelumnya ditangkap di Nagari Pematang Panjang karena dituduh mencuri kotak amal. Sementara Budri, ditangkap di Terminal Kiliran Jao atas tuduhan pencurian sepeda motor atau 'curanmor'. Kedua-duanya ditahan dalam sel yang sama atas tuduhan tersebut hingga akhirnya ditemukan tewas secara bersamaan. Ibu kandung korban, Yusmaidar (50), tidak menyangka jika kedua buah hatinya menemui ajal dengan cara demikian.

Sejumlah oknum polisi di Polsek Muaro Sijunjung dihadapkan ke persidangan atas tuduhan penganiayaan. Selain mengungkap sebab kematian kedua putranya, proses pencarian keadilan juga ditempuh oleh keluarga korban dengan meminta ganti-kerugian kepada pelaku tindak pidana dan institusi kepolisian. Dua Putusan Pengadilan Negeri Muaro Sijunjung menyatakan para terdakwa selaku anggota kepolisian, terbukti secara sah dan meyakinkan melakukan tindak pidana penganiayaan terhadap Faisal dan Budri. Namun, majelis hakim menolak permintaan restitusi yang dimintakan bersamaan dengan tuntutan pidana dalam perkara tersebut. Majelis hakim menganggap kematian korban bukanlah akibat dari perbuatan terdakwa.

Kasus penyiksaan tahanan seperti yang dialami Faisal dan Budri sebenarnya bukan yang pertama kali terjadi. Lembaga Bantuan Hukum (LBH) Jakarta misalnya mencatat, setiap tahunnya tak kurang dari 20 laporan tentang penyiksaan yang diterima oleh tersangka oleh pihak kepolisian. ${ }^{1}$ Maraknya kasus penyiksaan ini menandakan bahwa tindakan tersebut hampir menjadi kultur di institusi kepolisian dalam menangani tindak kejahatan.

Masalah korban dalam tindak penyiksaan merupakan hal yang paling memprihatinkan. Sebagai pihak yang dirugikan, selain tidak mendapatkan keadilan karena pelakunya jarang yang ditindak, korban acap kali tidak mendapatkan pemulihan akibat penderitaan yang dialami dari tindakan penyiksaan tersebut. Ketidakberdayaan korban karena merupakan pihak yang

${ }^{1}$ Ada 20 Laporan Penyiksaan Tiap Tahun, http://www.bantuanhukum.or.id/web/ada-20laporan-penyiksaan-tiap-tahun/ 
sedang menjalani proses hukum (sebagai tersangka), penyiksaan yang dialami, dianggap sebagai suatu yang legal. Apalagi jika dari tahap penyelidikan, seorang tersangka yang tidak didampingi oleh penasihat hukumnya, potensi untuk mendapatkan penyiksaan sangat terbuka lebar.

Melalui Undang-Undang Nomor 13 Tahun 2006 tentang Perlindungan Saksi dan Korban, keadilan bagi korban penyiksaan seharusnya dapat dimaksimalkan. Dalam ketentuan dimaksud, ada mekanisme ganti-kerugian yang dapat ditempuh oleh korban untuk menuntut hak-haknya yang dirugikan akibat suatu tindak pidana. Ada dua bentuk pemulihan yang disediakan negara bagi korban dalam tindak pidana, yakni restitusi dan kompensasi. Restitusi diberikan oleh pelaku tindak pidana, sementara kompensasi diberikan oleh negara untuk korban pelanggaran HAM berat.

Proses pemulihan korban penyiksaan yang dialami oleh Faisal dan Budri ternyata tidak mudah diberikan. Walaupun senyatanya penyiksaan yang dilakukan oleh oknum kepolisian sudah dapat dibuktian di pengadilan, namun korban tetap tidak mendapatkan hak-haknya sebagaimana yang diamanatkan dalam undang-undang. Kegagalam korban penyiksaan medapatkan hakhaknya yang nyata-nyata dirugikan akibat adanya tindak penyiksaan dalam proses penegakan hukum menjadi pokok pembahasan dari penelitian ini. Hal mana, persoalan tersebut berkisar pada pertanyaan-pertanyaan tentang konstruksi peraturan perundang-undangan terkait mekanisme pemulihan hakhak korban penyiksaan, tinjauan terhadap putusan pengadilan, dan faktor yang sangat signifikan menyebabkan gagalnya pemulihan hak korban dari proses yang sudah dilakukan.

\section{Kedudukan Korban dalam Sistem Peradilan Pidana}

Korban merupakan pihak yang merasakan akibat negatif akibat tindak pidana tersebut. Dimana, secara yuridis, akibat negatif tersebut berupa penderitaan fisik, mental, dan/atau kerugian ekonomi. ${ }^{2}$ Pada intinya, korban menjadi pihak yang paling dirugikan kepentingan hukumnya akibat suatu tindak pidana. Namun demikian, perhatian hukum pidana dalam praktik penegakan hukum, lebih dititikberatkan kepada pelaku tindak pidana ketimbang korban.

Esensi yang menonjol dari proses penegakan hukum pidana adalah bagaimana mengenakan sanksi pidana bagi pihak-pihak yang melanggar

2 Pasal 1 angka 2 UU No. 13 Tahun 2006 tentang Perlindungan Saksi dan Korban. 


\section{Syafridatati \& Refki Saputra}

ketentuan hukum pidana yang melakukan tindak pidana. Hukum acara pidana sebagian besar mengatur tatacara memperlakukan pelaku tindak pidana. Yakni, semenjak dimulainya proses hukum acara pidana melalui penyelidikan dan penyidikan, hingga penjatuhan sanksi pidana kepada terdakwa yang terbukti secara sah dan meyakinkan melakukan tindak pidana. Sementara korban tindak pidana dan masyarakat secara otomatis diwakili oleh negara dengan cara mengadili dan menjatuhkan pidana yang setimpal dengan perbuatan terdakwa. ${ }^{3}$ Pandangan tersebut mendominasi praktik peradilan pidana, akibatnya korban sebagai pihak yang terlanggar haknya akibat dari tindak pidana sering diabaikan oleh sistem peradilan pidana.

Secara normatif, Undang-Undang No. 8 Tahun 1981 tentang Hukum Acara Pidana (KUHAP) tidak cukup memberikan perlindungan jika dibandingkan perlindungan terhadap hak-hak tersangka atau terdakwa. KUHAP lebih melihat Saksi sebagai bagian dari alat bukti dan kurang mengatur tentang Saksi sebagai pihak yang perlu dilindungi dan dipulihkan hak-haknya, terutama korban. ${ }^{4}$ Dengan mengutip Reiff (1979), Mudzakkir menganggap partisipasi korban kejahatan dalam sistem peradilan pidana dipandang sebagai "nothing more than a piece of evidence" yang posisinya berada di luar sistem (outsider), bukan menjadi pihak yang sangat berkepentingan dan terlibat dalam sistem (insider). ${ }^{5} \mathrm{Hal}$ ini menunjukkan, dalam sistem peradilan pidana, posisi korban sama sekali tidak diperhitungkan. Perhatian negara jauh lebih besar kepada pihak yang diduga pelaku kejahatan. Akibatnya, kepentingan korban tidak diakomodir dalam peradilan pidana.

Padahal, tujuan dari hukum pidana adalah mengembalikan keseimbangan yang tergoncang akibat tindak pidana yang terjadi. Tidaklah mungkin keseimbangan bisa terjadi kalau hanya memperbaiki salah satu bagian saja, yakni pelaku tindak pidana. Melainkan harus juga memperbaiki keadaan yang dirusak oleh tindak pidana. Korban yang merupakan pihak yang menderita kerugian secara langsung, baik materil maupun immateril dari suatu tindak pidana atau kejahatan, karena menjadi objek sasaran dari tindak pidana harus juga dikembalikan keadaannya ke kondisi semula sebelum terjadinya tindak pidana.

${ }^{3}$ Bambang Waluyo, Viktimologi Perlindungan Korban \& Saksi (Jakarta: Sinar Grafika, 2011),

h. 2

${ }^{4}$ Supriyadi Widodo Edyyono, Pemetaan Undang-Undang Terkait dengan Perlindungan Saksi dan Korban (Jakarta: 2005), h. 13

${ }^{5}$ Mudzakkir, Kedudukan Korban Tindak Pidana dalam Sistem Peradilan Pidana Indoensia Berdasarkan KUHP dan RUU KUHP, Jurnal Ilmu Hukum, Vol. 14, No. 1 Maret 2011: 28-62, h. 29 . 
Menurut Prof. Mardjono Reksodiputro, dari pendekatan kriminologi ada beberapa alasan mengapa korban kejahatan perlu mendapat perhatian, yaitu, pertama, sistem peradilan pidana dianggap terlalu banyak memberikan perhatian kepada permasalahan dan peranan pelaku kejahatan (offenderedcentered); kedua, terdapat potensi informasi dari korban kejahatan untuk memperjelas dan melengkapi penafsiran kita atas statistik kriminal (terutama statistik yang berasal dari kepolisian); ini dilakukan melalui survei tentang korban kejahatan (victims surveys); ketiga, makin disadari bahwa disamping korban kejahatan konvensional (kejahatan-jalanan; street crime) tidak kurang pentingnya untuk memberi perhatian kepada korban kejahatan nonkonvesional (antara lain kejahatan korporasi dan kejahatan kerah-putih) maupun korban-korban dari penyalahgunaan kekuasaan (abuse of economic power and/or public power). ${ }^{6}$

Salah satu wadah internasional yang mangarusutamakan pentingnya perlindungan bagi korban kejahatan adalah melalui Declaration of Basic Principle of Justice for Victim of Crime and Abuse of Power, yang menyatakan perlindungan korban antara lain dalam wujud sebagai berikut:

a. Korban kejahatan harus diperlakukan dengan penuh rasa hormat terhadap martabatnya, serta diberi hak untuk segera menuntut ganti kerugian. Mekanisme hukum dan administrasinya harus dirumuskan dan disahkan untuk memungkinkan korban kejahatan memperoleh ganti kerugian.

b. Korban kejahatan harus diberi informasi mengenai peran mereka, jadwal waktu, dan kemajuan yang telah dicapai dalam penanganan kasusnya. Penderitaan dan keprihatinan korban kejahatan, harus selalu ditampilkan dan disampaikan pada setiap tingkatan proses. Jika ganti kerugian yang menyeluruh tidak dapat diperoleh dari pelaku dalam kasus-kasus kerugian fisik atau mental yang parah, negara berkewajiban memberi ganti kerugian kepada korban kejahatan atau keluarganya.

c. Korban kejahatan harus menerima gantu kerugian dari pelaku kejahatan atau keluarganya.

Kongres PBB VII tahun 1985 tentang "The Prevention of Crime and The Treatment of Offenders" di Milan, Italia menyatakan bahwa "Victims right should

\footnotetext{
${ }^{6}$ Mardjono Reksodiputro, Hak Asasi Manusia dalam Sistem Peradilan Pidana (Jakarta: Pusat Pelayanan Keadilan dan Pengabdian Hukum Lembaga Kriminologi Universitas Indonesia), 2007, h. 102.
} 


\section{Syafridatati \& Refki Saputra}

be perceived as anintegral aspect of the total criminal justice system." (Hak-hak korban seharusnya menjadi bagian yang integral dari keseluruhan sistem peradilan pidana). Dalam Kongres PBB ini diajukan rancangan Resolusi tentang Perlindungan Korban ke Majelis Umum PBB yang kemudian menjadi Resolusi Majelis Umum PBB No. 40/34 tertanggal 29 November 1985 tentang "Declaration of Basic Principles of Justice for Victim of Crime and Abuse of Power." Deklarasi tersebut menjadi tonggak sejarah terhadap upaya melindungi kepentingan saksi dan korban dalam proses peradilan pidana di dunia internasional.

Posisi korban dalam peradilan pidana di Indonesia mulai diperkuat semenjak lahirnya Undang-Undang No. 13 Tahun 2006 tentang Perlindungan Saksi dan Korban. Paradigma korban yang sebelumnya sudah terwakili sepenuhnya negara, dalam hal ini oleh polisi dan jaksa, kemudian mengalami perkembangan. Eksistensi korban mulai tampak dalam tahapan pembuktian dengan memberikannya perlindungan untuk dapat memberikan kesaksian yang tanpa rasa takut. Bagi korban tindak pidana, perkembangan yang sangat signifikan adalah hak untuk mendapatkan pemulihan berupa restitusi atau ganti kerugian kepada pelaku tindak pidana. ${ }^{7}$ Melalui aturan ini diharapkan korban tindak pidana mendapatkan apa yang seharusnya menjadi haknya sebagai bagian dari elemen penting dari penegakan hukum pidana.

\section{Hukum Penyiksaan}

Dalam catatan sejarah, penyiksaan jamak terjadi pada tindakan pencarian informasi kepada seorang yang diduga memiliki informasi. Hal ini misalnya dikatakan oleh Evans dan Morgan (1998), bahwa tindakan penyiksaan pada era Yunani Kuno diistilahkan sebagai 'basanos', yang merujuk pada sebuah batu yang dapat digunakan untuk mengetes kadar kemurnian dari emas. Penyiksaan (basanos) tersebut dilakukan berdasarkan pada asumsi jika para budak akan selalu mengatakan kebenaran bila disiksa. ${ }^{8}$ Artinya, penyiksaan erat kaitannya dengan suatu relasi kuasa antara pelaku dengan korban yang disiksa dan untuk tujuan yang spesifik.

Dalam ketentuan Pasal 1 Convention against Toture and Other Cruel, Inhuman and Degrading Treatment and Punishment 1984 (atau CAT), yang juga diadopsi oleh Pasal 1 angka 4 UU No. 39 Tahun 1999 tentang Hak Asasi Manusia, yang menjabarkan pengertian penyiksaan adalah sebagai berikut:

7 Pasal 7 ayat (1) huruf b UU No. 13 Tahun 2006.

8 Pranoto Iskandar, Tindak Penyiksaan dan Hukum Internasional, Jurnal Pandecta, Volume 6 Nomor 2 Juli 2011, http://journal.unnes.ac.id/nju/index.php/pandecta, h. 163. 
"Penyiksaan adalah setiap perbuatan yang dilakukan dengan sengaja, sehingga menimbulkan rasa sakit atau penderitaan yang hebat, baik jasmani maupun rohani, pada seseorang untuk memperoleh pengakuan atau keterangan dari seseorang atau dari orang ketiga, dengan menghukumnya atas suatu perbuatan yang lelah dilakukan atau diduga telah dilakukan oleh seseorang atau orang ketiga, atau mengancam atau memaksa seseorang atau orang ketiga. atau untuk suatu alasan yang didasarkan pada setiap bentuk diskriminasi, apabila rasa sakit atau penderitaan tersebut ditimbulkan oleh, atas hasutan dari, dengan persetujuan, atau sepengetahuan siapapun dan atau pejabat publik"

Dari konvensi terebut, penyiksaan dapat dijabarkan menjadi dua hal, yakni, pertama, tujuan dilakukannya penyiksaan adalah untuk memperoleh pengakuan atau keterangan, dan kedua, dilakukan atas persetujuan atau sepengetahuan pejabat pemerintah. Adanya faktor kekuasaan ini menyebabkan tindakan penyiksaan menjadi perhatian masyarakat internasional. Dimana, perhatian dunia tentang tindak penyiksaan sudah dimulai semenjak Declaration Universal of Human Rights atau Deklarasi Umum Hak Asasi Manusia (DUHAM) oleh Majelis Umum Perserikatan Bangsa-bangsa tahun 1948, sebagai bagian dari usaha untuk makin menghargai hak asasi dan martabat kemanusiaan. Kemudian, secara lebih spesifik, dalam Pasal 7 International Convention on Civil and Political Rights (ICCPR), sudah mengatur dengan sangat jelas tentang perlindungan manusia dari ancaman penyiksaan yang dilakukan pihak lain. Dimana dikatakan bahwa : "No one shall be subjected to torture or to cruel, inhuman or degrading treatment or punishment. In particular, no one shall be subjected without his free consent to medical or scientific experimentation". (Tidak seorangpun boleh dikenai penyiksaan, atau perlakuan atau hukuman yang keji, tidak manusiawi atau merendahkan martabatnya, khususnya tidak seorangpun, tanpa persetujuannya secara sukarela dapat dijadikan eksperimen medis atau ilmiah).

Indonesia pada dasarnya sudah meratifikasi ${ }^{9}$ CAT pada 28 September 1998 melalui UU No. 5 Tahun 1998. Maka secara hukum internasional, Indonesia terikat dengan norma-norma anti-penyiksaan tersebut untuk

${ }^{9}$ Meskipun meratifikasinya, Indonesia tidak menerima seluruh pasal dalam Konvensi Menentang Penyiksaan itu. Indonesia melakukan reservasi (pensyaratan) atau deklarasi (pernyataan) khusus pada pasal-pasal tertentu. (a) Deklarasi terhadap pasal 20 ayat 1,2, dan 3 (prosedur penyelidikan), dimana Indonesia tidak mengakui kewenangan Komite Menentang Penyiksaan untuk melakukan penyelidikan jika ada petunjuk yang kuat bahwa telah atau terus terjadi penyiksaan secara sistematik di wilayah Indonesia serta menyatakan bahwa hal-hal yang diatur dalam pasal 20 ayat 1, 2, dan 3 dari Konvensi hanya dapat diimplementasikan jika tidak membahayakan pada kedaulatan (sovereignty) dan integritas teritorial Indonesia. Agung Yudha Wiranata, Konvensi Anti Penyiksaan, Seri Bahan Bacaan Kursus HAM untuk Pengacara XI tahun 2007 (Jakarta: Lembaga Studi dan Advokasi untuk Masyarakat), h. 18. 


\section{Syafridatati \& Refki Saputra}

melakukan langkah-langkah mencegah dan memerangi tindakan penyiksaan dalam wilayah yuridisnya. Misalnya apa yang disebutkan dalam Pasal 14 CAT angka 1 yaitu :

"Setiap Negara Pihak harus menjamin agar dalam sistem hukumnya korban dari suatu tindak penyiksaan memperoleh ganti-rugi dan mempunyai hak untuk mendapatkan kompensasi yang adil dan layak, termasuk sarana untuk rehabilitasi sepenuh mungkin. Dalam peristiwa korban meninggal dunia sebagai akibat tindak penyiksaan, ahli warisnya berhak mendapatkan gantirugi."

Praktiknya di Indonesia, tindakan penyiksaan tidak dibedakan dengan bentuk pelanggaran hukum pidana lainnya. Selain dikenakan Pasal 351 sebagai penganiayaan, tindakan penyiksaan biasanya juga dikenakan Pasal 422 KUHP yang menyatakan bahwa: "Seorang pejabat yang dalam suatu perkara pidana menggunakan sarana paksaan, baik untuk memeras pengakuan, maupun untuk mendapatkan keterangan, diancam dengan pidana penjara paling lama empat tahun." Pasal ini jelas belum sepenuhnya melingkupi tindakan penyiksaan yang dimaksud dalam konvensi anti-penyiksaan. Akibatnya, gradasi tindak penyiksaan menjadi "turun" menjadi tindak pidana penganiayaan biasa. Selain tidak memberikan efek jera bagi pelaku, karena ringannya hukuman, banyak pelaku yang tidak tersentuh hukum, serta berpotensi untuk mengulangi perbuatannya. Dengan demikian, regulasi KUHP tidak dapat menjadi sarana untuk menghentikan (non recurence) berulangnya praktik-praktik penyiksaan. ${ }^{10}$

Penyiksaan juga merupakan bentuk pelanggaran HAM, karena dilakukan oleh aparat negara, bukan oleh individu terhadap individu lainnya. ${ }^{11}$ Maka, negara harus bertanggungjawab atas tindakan penyiksaan tersebut sebagai bentuk tanggungjawab negara (state responsibility), yang merupakan prinsip fundamental dalam hukum internasional. ${ }^{12}$ Disinilah letak perbedaan antara pelanggaran HAM dengan tindak kejahatan biasa. ${ }^{13}$ Pemerintah dalam rangka penghormatan, perlindungan, penegakan serta pemajuan HAM

${ }^{10} \mathrm{http} / / /$ lsam.or.id/2015/06/indonesia-masih-butuh-pengaturan-penyiksaan-dalam-

rancangan-kuhp-rancangan-kuhap-dan-ruu-penyiksaan/, diunduh pada 15 Juni 2016.

${ }_{11}$ Nurhidayatuloh, Gross Violations of Human Rights: Praktik Pengadilan HAM Internasional dan Putusan Mahkamah Konstitusi di Indonesia, Makalah Training Tingkat Lanjut Rule of Law dan Hak Asasi Manusia bagi Dosen Hukum dan HAM, Jakarta 3-6 Juni 2015, (PUSHAM UII), h. 7

12 Nurhidayatuloh, Gross Violations of Human Rights: Praktik Pengadilan HAM Internasional dan Putusan Mahkamah Konstitusi di Indonesia, h. 9

${ }^{13}$ Pranoto Iskandar, Tindak Penyiksaan dan Hukum Internasional, h. 165. 
tersebut, harus mengupayakan langkah-langkah yang efektif untuk mencegah dan menanggulangi tindak penyiksaan yang terjadi.

\section{Perlindungan Korban Penyiksaan di Indonesia}

Perlindungan hukum terhadap korban kejahatan atau tindak pidana, khususnya dalam bentuk pemulihan secara materil dilakukan dalam bentuk ganti-kerugian yakni berupa restitusi. Sementara, untuk korban pelanggaran HAM berat, selain restitusi juga dapat dimintakan ganti-kerugian kepada negara berupa kompensasi. Hal ini misalnya terdapat dalam Pasal 7 ayat (1) UU PSK yang menyatakan bahwa korban melalui LPSK berhak mengajukan kompensasi untuk kasus pelanggaran HAM berat dan restitusi yang menjadi tanggungjawab pelaku tindak pidana.

Adapun restitusi dan kompensasi ini merupakan istilah yang dalam penggunaannya sering dipertukarkan (interchangable). Menurut Stephen Schafer, perbedaan antara kedua istilah tersebut adalah sebagai berikut: ${ }^{14}$ pertama, kompensasi bersifat keperdataan (civil character). Kompensasi timbul dari permintaan korban, dan dibayar oleh masyarakat atau merupakan bentuk pertanggungjawaban masyarakat/negara (the responsibility of the society). Dasar kompensasi dari negara adalah sesuatu yang fundamental bahwa setiap resiko kejahatan, sebagai bentuk solidaritas sosial. Kompensasi diberikan karena seseorang menderita kerugian materil dan kerugian yang bersifat immaterial; kedua, restitusi bersifat pidana (penal in caharacter), timbul dari putusan pengadilan pidana dan dibayar oleh terpidana atau merupakan wujud pertanggungjawaban pidana (the responsibility of the offender).

Hal ini misalnya dapat dilihat dari pengertian restitusi dan kompensasi dalam Peraturan Pemerintah No. 44 Tahun 2008 tentang Pemberian Kompensasi, Restitusi dan Bantuan Kepada Saksi dan Korban. Restitusi dalam ketentuan ini dijelaskan sebagai ganti kerugian yang diberikan kepada Korban atau Keluarganya oleh pelaku atau pihak ketiga, dapat berupa pengembalian harta milik, pembayaran ganti kerugian untuk kehilangan atau penderitaan, atau penggantian biaya untuk tindakan tertentu (Pasal 1 angka 5). Sementara, kompensasi diberikan oleh negara karena pelaku tidak mampu memberikan ganti kerugian sepenuhnya yang menjadi tanggung jawabnya (Pasal 1 angka 4). Dari pengertian tersebut, seolah-olah kompensasi diberikan karena restitusi yang ditujukan kepada pelaku tindak pidana tidak bisa dipenuhi. Peraturan ini

14 Pranoto Iskandar, Tindak Penyiksaan dan Hukum Internasional, h. 59. 


\section{Syafridatati \& Refki Saputra}

tidak secara tegas menempatkan kompensasi sebagai tanggungjawab negara kepada korban. ${ }^{15}$

Secara konseptual, kompensasi yang dibayarkan apabila pelaku tidak mampu membayar (membayar restitusi) dianggap telah menyalahi aturan hukum internasional tentang HAM. Kompensasi yang dikenal secara universal diberikan kepada korban, bukan karena pelaku tidak mampu membayar, melainkan sudah menjadi kewajiban negara (state obligation) untuk memenuhinya ketika terjadi pelanggaran hak asasi manusia yang berat dan mengakibatkan adanya korban. ${ }^{16} \mathrm{Hal}$ ini berbeda dengan restitusi yang bersifat pidana, yang menurut Romli Atmasasmita merupakan suatu perwujudan dari resosialisasi tanggungjawab pelaku sebagai warga masyarakat. Dimana, melalui proses resosialisasi tersebut dimaksudkan dan diharapkan agar tertanam rasa tanggugjawab sosial dalam diri pelaku. ${ }^{17}$ Wajar jika terhadap restitusi baru dapat diterima apablia terhadap terdakwa itu dijatuhi hukuman ataupun diperlakukan tindakan. Maka, apabila terdakwa itu dibebaskan dari segala tuduhan ataupun dilepaskan dari segala tuntutan, maka tuntutan gantirugi terhadap terdakwa tidak bisa diberikan. ${ }^{18}$

Penyiksaan sebagai bentuk pelanggaran HAM, namun tidak termasuk pelanggaran HAM berat sebagaimana yang dimaksud dalam UU No. 26 Tahun 2000 tentang Pengadilan HAM. Maka mekanisme perlindungan hukum terhadap korban penyiksaan, hanya mengikuti aturan selayaknya tindak pidana pada umumnya, yakni berupa restitusi. Itupun bisa dikabulkan jika perbuatan penyiksaan (dalam hal ini penganiayaan) terbukti secara sah dan meyakinkan di pengadilan. Jika mengacu kepada KUHAP, restitusi yang diberikan hanya dibatasi pada kerugian secara nyata ditimbulkan akibat tindak pidana (materil). Sedangkan sifatnya immateril yang diderita korban tidak dapat diajukan dalam penggabungan gugatan tersebut karena masih

${ }^{15}$ Dalam rezim pengadilan HAM berat, korban selain mendapatkan kompensasi, juga mendapatkan restitusi sebagaimana yang diatur dalam Peraturan Pemerintah Nomor 3 Tahun 2002 tentang Kompensasi, Restitusi dan Rehabilitasi Terhadap Korban Pelanggaran HAM Berat. Dua aturan yang berbeda ini menandakan bahwa tidak adanya sinkronisasi peraturan yang mengatur ikhwal pemulihan korban kejahatan. Wahyu Wagiman dan Zainal Abidin, Praktik Kompensasi dan Restitusi di Indonesia; Sebuah Kajian Awal (Jakarta: ICW dan ICJR, 2007), h. 5

16 Wahyu Wagiman dan Zainal Abidin, Praktik Kompensasi dan Restitusi di Indonesia, h. 23

17 Zulkipli, Zulkipli, Kompensasi dan Restitusi Bagi Korban Pelanggaran Hak Asasi Manusia yang Berat (Jakarta: Tesis Program Pasca Sarjana Fakultas Hukum Universitas Indonesia, 2011), h.64

18 Oemar Seno Adji, Herziening, Ganti-rugi, Suap, Perkembangan Delik (Jakarta: Penerbit Erlangga, 1984), h. 75 
memerlukan pembuktian yang relatif sulit, lama dan berbelit-belit, sehingga harus melalui gugatan perkara biasa. ${ }^{19}$

Adapun proses pengajuan restitusi oleh korban tindak pidana adalah dengan terlebih dahulu mengajukan permohonan kepada LPSK. ${ }^{20}$ LPSK akan memeriksa permohonan dan mengambil keputusan apakah pemohonan (korban atau ahli warisnya) memenuhi persyaratan untuk diberikan restitusi. Keputusan LPSK tersebut kemudian disampaikan kepada penuntut umum untuk diajukan bersamaan dengan surat tuntutan pidana kepada hakim di pengadilan. Hakim kemudian memutus apakah permohonan restitusi yang dimintakan dapat dikabulkan atau ditolak sejalan dengan pembuktian tindak pidana yang diakwakan kepada terdakwa.

\section{Hambatan Pemulihan Hak Korban Penyiksaan di Tahanan Kepolisian Sektor Sijunjung Sumatera Barat}

Putusan PN Muaro yang menyatakan oknum Polsek Sijunjung bersalah melakukan tindak pidana penganiayaan. Hal ini, membuktikan bahwa telah terjadi tindakan penyiksaan terhadap Faisal dan Budri. Walaupun vonis sudah dijatuhkan, namun bukan berarti keadilan sudah dipenuhi, khususnya bagi korban. Upaya pemulihan hak korban yang diajukan melalui permintaan gantikerugian dalam bentuk restitusi ternyata tidak bisa dipenuhi. Ketidakjelasan konsep penyiksaan dalam tatanan hukum di Indonesia menjadi hambatan yang paling utama. Selain itu juga terkait pola hubungan antara LPSK sebagai pihak yang paling otoritatif dalam hal perlindungan saksi dan korban dengan penegak hukum, dalam hal Jaksa Penuntut Umum yang belum terlembaga dengan baik.

Ahli waris korban mengajukan restitusi atas kematian dari Faisal dan Budri. Walaupun perbuatan penganiayaan yang dituduhkan kepada terdakwa dianggap terbukti, namun hakim memandang kematian korban bukan disebabkan oleh penganiayaan tersebut, melainkan sebab yang lain. Hakim mendasarkan putusannya kepada keterangan ahli yang menyatakan kematian korban diakibatkan kekerasan benda tumpul pada leher yang menyebabkan mati lemas. Lebih lanjut majelis hakim menyatakan sebagai berikut:

${ }^{19}$ Zulkipli, Kompensasi dan Restitusi Bagi Korban Pelanggaran Hak Asasi Manusia yang Berat (Jakarta: Tesis Program Pasca Sarjana Fakultas Hukum Universitas Indonesia, 2011), h.82

20 Pasal 20 ayat (3) PP No. 44 Tahun 2008 


\section{Syafridatati \& Refki Saputra}

"Menimbang, bahwa perbuatan yang dilakukan oleh para terdakwa tersebut tidak dilakukan di daerah leher sehingga menyebabkan mati lemas, dan menurut keterangan ahli dr. Rika Susanti, SPF perbuatan yang dilakukan oleh para terdakwa tidak pada daerah yang menyebabkan kematian... Bahwa berdasarkan fakta di persidangan, petunjuk serta keterangan dari Ahli forensik tersebut di atas, Majelis berkesimpulan bahwa matinya kedua tahanan Polsek Sijunjung yaitu Budri M. Zen dan Faisal Akbar bukan karena perbuatan para terdakwa." 21

Fakta bahwa korban yang ditemukan tewas tergantung di kamar mandi ruang tahanan Polsek Sijunjung, tidak bisa dibuktikan ada kaitannya dengan penganiayaan atau lebih tepatnya penyiksaan yang dilakukan pelaku. Dengan demikian, restitusi yang diajukan kepada pelaku ditolak oleh hakim karena penganiayaan yang terbukti bukanlah penganiayaan yang menyebabkan kematian korban (sebagaimana dasar dari pengajuan restitusi), melainkan tindak pidana penganiayaan biasa. Oleh karena restitusi dikaitkan dengan kesalahan pelaku, maka dengan tidak terbuktinya pelaku yang menyebabkan matinya korban, maka hakim memutus tidak bisa membebankan pelaku dengan membayarkan restitusi kepada korban. Lebih lanjut, hakim mengatakan:

“Menimbang, bahwa kematian Budri M. Zen bukanlah diakibatkan oleh perbuatan para terdakwa, oleh karenanya tuntutan restitusi atau ganti kerugian yang diajukan oleh keluarga korban mengenai biaya penyelenggaraan jenazah tersebut tidak tepat dibebankan kepada para terdakwa;

Menimbang, bahwa tuntutan kedua yang berupa biaya penghasilan Budri M. Zen yang hilang karena korban sudah meninggal, karena tuntutan tersebut bersifat immaterial dimana merupakan kejadian yang belum pasti terjadi dimasa yang akan datang maka kerugian tersebut juga tidak dapat dibebankan kepada para terdakwa." 22

Restitusi yang diminta oleh korban dikaitkan kesalahan terdakwa sebagai penyebab matinya korban. Sementara, fakta persidangan menunjukkan matinya korban bukan disebabkan oleh penganiayaan yang dilakukan terdakwa. Walaupun pada saat proses pemeriksaan perkara sebenarnya hakim sudah menawarkan besaran restitusi yang bisa diperoleh korban berdasarkan tingkat pelanggaran dan kemampuan pelaku, yakni sebesar Rp. 10 juta rupiah per-orang. ${ }^{23}$ Namun, korban menolak karena tidak sesuai dengan yang

${ }^{21}$ Putusan No. 136/Pid.B/2012/PN.MR. h. 109

22 Putusan No. 136/Pid.B/2012/PN.MR, h. 116

${ }^{23}$ Wawancara dengan Ibu Reni Novita, SH selaku Jaksa Penuntut Umum (JPU) perkara Syamsul Bahri dan Rendi Agusta pada 15 Juni 2016. 
dimintakan dalam tuntutan restitusi. ${ }^{24} \mathrm{Hal}$ ini menunjukkan bahwa pertimbangan hakim dalam mengabulkan atau tidak mengabulkan restitusi, dibatasi pada kesalahan pelaku atas penganiayaan saja, tapi bukan penyebab dari kematian korban.

Terlepas dari kesalahan terdakwa sebagai penyebab kematian korban atau tidak, secara hukum terdakwa sudah melakukan penyiksaan sebagai suatu kebenaran materiil. Sebagai bentuk pelanggaran HAM, harusnya pihak yang bertanggungjawab dalam tindakan tersebut bukan hanya pelaku, akan tetapi juga institusi yang dalam hal ini adalah Kepolisian Sektor Sijunjung. Tuntutan pemulihan hak, seharusnya bukan hanya restitusi melainkan juga kompensasi kepada institusi. Namun, kelemahan mekanisme kompensasi juga hanya dibatasi pada pelanggaran HAM berat, tidak termasuk penyiksaan. Hukum penyiksaan seharusnya memasukkan penyiksaan sebagai bentuk pelanggaran HAM, yang mana bagi korbannya dapat mengajukan kompensasi kepada negara sebagai pelaku pelanggaran HAM.

\section{Mekanisme Pemulihan Hak Korban Penyiksaan}

Korban yang merasa dirugikan haknya dan hendak mengajukan proses pemulihan diberikan ruang oleh peraturan perundang-undangan, yakni Undang-undang No. 13 Tahun 2006 jo. Peraturan Pemerintah No. 44 Tahun 2008. Adapun institusi yang diberikan mandat yang utama dalam mekanisme pemulihan hak-hak korban adalah LPSK. Namun, yang menentukan apakah korban berhak atas pemulihan atau tidak adalah pengadilan. Dalam proses pengajuan, terdapat pula peran dari penegak hukum lainnya, yakni Jaksa Penuntut Umum (JPU), apabila perkara pokoknya belum diputus oleh pengadilan (vide Pasal 28 PP No. 44 Tahun 2008). JPU disini berperan sebagai lembaga yang memintakan hak untuk pemulihan kepada hakim yang dimasukkan dalam Surat Tuntutannya bersamaan dengan perkara pokok. Adanya tiga lembaga yang memilki peran masing-masing dalam proses pemulihan ini selain menambah birokrasi juga ternyata dalam praktik tidak begitu efektif.

Dalam perkara Faisal dan Budri, keluarga korban lebih banyak berkomunikasi kepada LBH dan juga LPSK dalam proses permintaan restitusi. Sementara, restitusi yang dimintakan harus dimasukkan dalam surat tuntutan

${ }^{24}$ Alasan penolakan dari pihak keluarga korban, selain karena jauh dibawah tuntutan restitusi adalah karena hal demikian biasanya dilakukan untuk meringankan hukuman pelaku. Wawancara dengan kuasa hukum korban Bpk. Vino Octavia, SH pada 25 Juni 2016. 


\section{Syafridatati \& Refki Saputra}

dari JPU di pengadilan. Sifat dari restitusi yang mengharuskan adanya kesalahan dari terdakwa, maka JPU memiliki peran yang sangat penting dalam perumusan restitusi. Yakni dalam hal menentukan pasal mana yang terbukti menurut fakta persidangan. ${ }^{25}$ Namun, disisi lain, JPU sangat rentan untuk dipengaruhi oleh pihak dari terdakwa. Khususnya dalam kasus penyiksaan, yang mana pelakunya adalah pihak kepolisian yang notabene adalah mitra JPU dalam penyidikan dan penuntutan perkara pidana.

Tidak adanya aturan teknis dilapangan terkait dengan permintaan restitusi ini, membuat pihak-pihak yang terlibat memiliki persepsi berbeda. Secara teknis dilapangan misanya, pengajuan restitusi dalam perkara Faisal dan Budri, lebih banyak disiapkan oleh LPSK dan korban yang diwakili oleh LBH Padang. Jadi, JPU hanya menyampaikan surat pengantar kepada majelis hakim untuk menyampaikan permintaan restitusi. ${ }^{26} \mathrm{Hal}$ ini yang kemudian menyebabkan permintaan restitusi oleh pihak korban ditolak oleh hakim. Pasalnya, pihak korban meminta restitusi atas dasar kesalahan terdakwa yang menyebabkan kematian korban. Semetara, berdasarkan fakta persidangan yang terbukti adalah bukan terdakwa yang menyebabkan kematian korban. Dengan demikian, persepsi yang belum sama antara instansi yang berwenang dalam pemenuhan hak-hak korban penyiksaan membuat proses pemulihan hak-hak korban penyiksaan semakin tidak menentu.

\section{Penutup}

Rezim perlindungan saksi dan korban di Indonesia sudah memasuki satu dasawarsa. Namun, korban belum sepenuhnya dilindungi dalam Sistem Peradilan Pidana (SPP) di Indonesia. KUHAP lebih melihat Saksi sebagai bagian dari alat bukti dan kurang mengatur tentang Saksi sebagai pihak yang perlu dilindungi dan dipulihkan hak-haknya, terutama korban. Walaupun dalam undang-undang diluar KUHAP seperti UU LPSK, perlindungan korban sudah diakomodir dalam bentuk perlindungan selama menjalani proses hukum, baik sebagai saksi dan juga pemulihan kondisi kesehatan. Termasuk juga pemulihan hak-haknya yang dirampas dari suatu tindak pidana, dalam bentuk ganti-kerugian.

${ }^{25}$ Adapun Pasal yang dianggap terbukti dari sejumlah dakwaan yang diajukan JPU adalah dakwaan penganiayaan terhadap anak [Pasal 80 ayat (1) UU No. 23 Tahun 2002] dan penganiayaan yang mengakibatkan luka berat [Pasal 351 ayat (2) KUHP]. Lihat Surat Tuntutan Kejaksaan Negeri Muaro No. Reg.Perkara : PDM-39/SIJUN/Ep.1/11/2012

${ }^{26}$ Wawancara dengan Ibu Reni Novita, $\mathrm{SH}$ 
Dalam hal tindak penyiksaan, ketiadaan instrumen hukum yang khusus mengatur soal penyiksaan membuat upaya pemulihan hak-hak korban menemui jalan buntu. Penyiksaan yang masih diasosiasikan sebagai pelanggaran hukum pidana umum (KUHP), khususnya penganiayaan menegasikan bahwa sesungguhnya penyiksaan merupakan pelaggaran terhadap hak asasi manusia yang paling mendasar. Pada akhirnya, tanggungjawab negara dialihkan kepada tanggungjawab individu sebagai pelaku penganiayaan yang dalam hal ini akan melanggengkan praktik impunitas.

Aspek lainnya yang ikut menghambat pemulihan korban adalah ketidaksamaan persepsi dari aparat yang terlibat dalam hal perlindungan saksi dan korban. LPSK sebagai focal point ternyata belum mampu bekerja secara sinergis dengan Jaksa Penuntut Umum dalam hal perkara belum selesai diputus oleh pengadilan. Keberadaan LPSK seolah-olah menambah birokrasi dalam proses pemulihan korban. Maka dari itu perlu ada semacam nota kesepahaman antara LPSK dengan institusi kejaksaan dalam hal permintaan restitusi dan kompensasi yang dilanjutkan dengan aturan teknis yang dapat memaksimalkan proses pemulihan korban dilapangan.

\section{Pustaka Acuan}

\section{Buku}

Seno Adji, Oemar, Herziening, Ganti-rugi, Suap, Perkembangan Delik, (Jakarta: Penerbit Erlangga), 1984.

Waluyo, Bambang, Viktimologi Perlindungan Korban E Saksi, (Jakarta: Sinar Grafika), 2011.

Widodo Edyyono, Supriyadi, Pemetaan Undang-Undang Terkait dengan Perlindungan Saksi dan Korban, Jakarta, 2005.

\section{Jurnal}

Iskandar, Pranoto, Tindak Penyiksaan dan Hukum Internasional, Jurnal Pandecta, Volume 6 Nomor 2 Juli 2011, http://journal.unnes.ac.id/nju/index.php/ pandecta.

Mudzakkir, Kedudukan Korban Tindak Pidana Dalam Sistem Peradilan Pidana Indoensia Berdasarkan KUHP dan RUU KUHP. Jurnal Ilmu Hukum, Vol. 14, No. 1 Maret 2011 


\section{Syafridatati \& Refki Saputra}

Reksodiputro, Mardjono, Hak Asasi Manusia dalam Sistem Peradilan Pidana. Jakarta: Pusat Pelayanan Keadilan dan Pengabdian Hukum Lembaga Kriminologi Universitas Indonesia, 2007.

Widodo Eddyono, Supriyadi. Pemetaan Legislasi Indonesia Terkait Dengan Perlindungan Saksi dan Korban, https://perlindungansaksi.files.wordpress.com/2008/07/ pemetaanperaturan-saksi.pdf.

Wagiman, Wahyu dan Zainal Abidin, Praktik Kompensasi dan Restitusi di Indonesia: Sebuah Kajian Awal. Jakarta: Indonesia Corruption Watch, Institute for Criminal Justice Reform, Koalisi Perlindungan Saksi, 2007.

Zulkipli, Kompensasi dan Restitusi Bagi Korban Pelanggaran Hak Asasi Manusian yang Berat. Tesis. Jakarta: Program Pasca Sarjana Fakultas Hukum Universitas Indonesia, 2011.

Nurhidayatuloh. Gross Violations of Human Rights: Praktik Pengadilan HAM Internasional dan Putusan Mahkamah Konstitusi di Indonesia, Makalah Training Tingkat Lanjut Rule of Law dan Hak Asasi Manusia bagi Dosen Hukum dan HAM, Jakarta 3-6 Juni 2015. PUSHAM UII.

\section{Peraturan Perundang-undangan}

Undang-undang No. 13 Tahun 2006 tentang Perlindungan Saksi dan Korban. Undang-undang No. 26 Tahun 2000 tentang Pengadilan Hak Asasi Manusia. Undang-undang No. 8 Tahun 1981 tentang Hukum Acara Pidana.

Peraturan Pemerintah No. 44 Tahun 2008 tentang Pemberian Kompensasi, Restitusi dan Bantuan Kepada Saksi dan Korban.

\section{Putusan Pengadilan}

Putusan Pengadilan Negeri Muaro No. 135/Pid.B/2012/PN.MR Putusan Pengadilan Negeri Muaro No. 136/Pid.B/2012/PN.MR Surat Tuntutan Kejaksaan Negeri Muaro No. Reg.Perkara : PDM39/SIJUN/Ep.1/11/2012 